\title{
LAMANG DAN TRADISI MALAMANG PADA MASYARAKAT MINANGKABAU
}

\section{LAMANG AND MALAMANG TRADITION IN MINANGKABAU SOCIETY}

\author{
Refisrul \\ Balai Pelestarian Nilai Budaya (BPNB) Sumatera Barat \\ Jl. Raya Belimbing No 16 A Kuranji Kota Padang \\ e-mail: refisruljon@yahoo.co.id
}

\begin{abstract}
Abstrak
Lamang adalah makanan khas masyarakat Minangkabau yang terbuat dari beras puluik dengan wadah dari talang (bambu). Membuat lamang merupakan tradisi masyarakat Minangkabau sejak dahulu dan biasa disebut dengan tradisi malamang. Lamang dan tradisi malamang menarik dan perlu diketahui lebih jauh terutama keberadaannya dalam kehidupan masyarakat Minangkabau. Kajian/penelitian ini menggunakan pendekatan kualitatif untuk mendapatkan data dan informasi yang lengkap dan mendalam. Tradisi malamang merupakan ekspresi masyarakat Minangkabau terhadap bentuk pemenuhan biologis dan hubungan sosial sesama mereka, baik dalam lingkup kerabat maupun masyarakat yang lebih luas. Adanya tradisi malamang semakin memperkuat ikatan kekerabatan, solidaritas dan simbol antara orangorang yang sekerabat. Artinya, makanan lamang (lemang), sebagai salah satu makanan tradisional, dan tradisi malamang terkait dengan folk culture nya yakni budaya Minangkabau.
\end{abstract}

Kata kunci; lamang, tradisi, Minangkabau

\begin{abstract}
Lamang is a typical food of Minangkabau society made from puluik rice with container from gutters (bamboo). Making lamang become the tradition of Minangkabau society since ancient times and commonly referred to as nightang tradition. Lamang and night traditions are interesting and need to know more in deep relationship in Minangkabau society life. This study uses a qualitative approach to data and information that is complete and in-depth. Nighttime tradition is the expression of Minangkabau society towards the form of biological fulfillment and their fellow social relation, both within the wider circle of relatives and society. The existence of the night tradition is stronger the bonds of kinship, solidarity and symbols between peers. That is, the food lamang (lemang), as one of traditional food, and night traditions related to the culture of its people Minangkabau culture.
\end{abstract}

Keywords: Lamang, Malamang, tradition, Minangkabau 


\section{PENDAHULUAN}

Masyarakat Minangkabau, dikenal kaya dengan khasanah budaya yang ditandai dengan banyaknya tradisi atau kebiasaan dalam kehidupan sehari-hari. Beberapa jenis tradisi yang terdapat dalam kehidupan masyarakat Minangkabau seperti tradisi mairiak pada waktu panen padi, bararak pada waktu baralek (pesta pernikahan), balimau, malamang, babako, dan lainlain. Aneka tradisi itu pada umumnya perlu dipertanyakan keberadaannya pada masyarakat Minangkabau sekarang, karena sudah jarang dilaksanakan, dan bahkan tidak dikenal lagi oleh generasi muda Minangkabau. Kalaupun masih ada, boleh dikatakan tata cara pelaksanaannya tidak seperti dahulu lagi atau sudah mengalami perubahan. Aneka tradisi di Minangkabau mengandung nilai luhur masyarakat Minangkabau yang seyogyanya tetap dijaga oleh masyarakat Minangkabau sekarang ini.

Salah satu tradisi yang telah berlangsung sejak dahulu di Minangkabau dan sudah jarang ditemui pada masa sekarang ini yakni tradisi malamang (membuat lamang). Lamang yaitu makanan dari ketan (puluik) yang dimasak bersama santan dan dikemas dalam wadah bambu, kemudian dimasak dengan perapian atau unggun yang sengaja dibuat untuk itu. Makanan lamang (lemang) merupakan salah satu makanan tradisional khas masyarakat Minangkabau, disamping randang, katupek (ketupat) dan lainnya. Malamang adalah proses pembuatan yang harus dilakukan untuk membuat lamang, dan tradisi membuat lamang itu lazim disebut dengan tradisi malamang. Umumnya, masyarakat Indonesia khususnya di Pulau Sumatera mengenal makanan berupa lamang (lemang) ini. ${ }^{1}$

Tradisi membuat lamang atau malamang dapat ditemui di seluruh wilayah Provinsi Sumatera Barat (baca; Minangkabau), baik di daerah darek (darat) seperti Solok, Payakumbuh, Agam, Tanah Datar, maupun di daerah pesisir pantai seperti Padang, Pariaman, dan Pesisir Selatan. Tradisi malamang ini terdapat di juga di daerah lain yang dahulunya merupakan rantau Minangkabau seperti Tapak Tuan (Aceh), Mukomuko (Bengkulu), Kerinci (Jambi), Tebing

\footnotetext{
${ }^{1}$ Di Kalimantan Selatan yang penduduk aslinya adalah dari etnis Banjar dan Dayak, lamang merupakan makanan yang istimewa, karena makanan dari beras lakatan (beras ketan) yang dimasak dengan air santan. Beras ketan kemudian dimasukkan ke dalam bumbung paring (ruas batang bambu) baik dibungkus dengan daun pisang atau tidak, bambu ini kemudian di panggang diatas bara api. Makanan ini merupakan makanan yang wajib ada dalam setiap ritual-ritual keagamaan yang dilakukan oleh masyarakat Dayak. Suku Banjar menyediakan lamang diacara Khatam Al-Qur'an, khitanan, pernikahan dan bahkan sampai kepada terapi buang sial (batatamba) dan lain sebagainya. Sedangkan bagi orang suku Dayak, terutama Dayak Pitap, lamang adalah pelengkap sesaji wajib ada dalam aruh (kenduri) adat seperti baharin, babalian (pengobatan penyakit khas Dayak), acara pemberian nama dan sebagainya. Cerita tentang orang Dayak dan Banjar yang menjadikan lamang sebagai makanan adat merupakan informasi bahwa lamang adalah sebuah makanan yang telah dikenal dalam waktu lama.
} 
Tinggi (Sumatera Utara) ${ }^{2}$, serta di Negeri Sembilan (Malaysia). Keberadaan malamang pada daerah-daerah tersebut diperkirakan dibawa oleh orang Minangkabau pada masa dahulu yang merantau dan kemudian menetap disana secara turun temurun. Tradisi malamang (membuat lemang) itu biasanya dilakukan menjelang bulan Ramadhan, lebaran (Idul Fitri dan Idul Adha), peringatan Maulid Nabi, baralek (pesta pernikahan), perayaan hari kematian, dan lain sebagainya. Hal itu mencerminkan bahwa, malamang tidak saja sebagai kebiasaan atau tradisi pada waktuwaktu tertentu oleh masyarakat Minangkabau, melainkan juga memiliki nilai ekonomis atau dimanfaatkan untuk pemenuhan kebutuhan keluarga.

Semarak tradisi malamang sangat terasa pada masa dahulu (sebelum tahun 1980-an) dimana setiap rumah pada waktu-waktu malamang akan membuat atau memasak lamang di halaman rumah secara bersama (tolong menolong). Kaum laki-laki dan perempuan akan bahu membahu membantu mulai dari penyiapan bahan, waktu pembakaran (memasak) hingga lamang itu siap untuk dimakan atau dihidangkan kepada tamu. Di beberapa kabupaten di Provinsi Sumatera Barat (Minangkabau), lamang dijadikan sebagai barang bawaan dari keluarga perempuan ke rumah keluarga laki-laki (manjalang), atau ketika seorang menantu perempuan berkunjung ke rumah mertuanya. Rasa lamang yang enak menyebabkan lamang juga dijadikan makanan sampingan yang dikonsumsi setiap saat karena makanan ini juga diperjualbelikan secara bebas. Di Tanah Datar, tepatnya di Nagari Limokaum, keahlian membuat lamang menjadi sumber mata pencaharian keluarga dengan menjualnya pada balai atau pakan (pasar tradisional) di daerah sekitarnya. Lamang Limokaum yang dijual oleh kaum wanita itu cukup dikenal dan diminati oleh para konsumen setiap hari di Kota Batusangkar. Disamping itu, daerah Sintuk Toboh Gadang Kabupaten Padang Pariaman juga merupakan salah satu daerah yang masih menjadikan lamang sebagai makanan adat (tradisi) yang mesti ada pada acara-acara tertentu seperti Maulud Nabi, acara kematian, dan bulan malamang (menjelang bulan Ramadhan).

Seiring dengan perkembangan zaman, yang cenderung mengabaikan nilai-nilai tradisional suatu masyarakat, ikut mempengaruhi keberadaan tradisi malamang dalam kehidupan masyarakat Minangkabau. Tradisi malamang ikut termarjinalkan dan bahkan dilupakan oleh masyarakat Minangkabau, ditandai dengan sudah jarang ditemukannya masyarakat Minangkabau yang membuat lamang ketika bulan puasa datang, lebaran haji, perayaan maulud, dan lain-lain, dan dikategorikan sebagai tradisi yang hampir punah di Minangkabau. Memudarnya tradisi

\footnotetext{
${ }^{2}$ Kota Tebing Tinggi dikenal juga sebagai Kota Lamang di Sumatera Utara, karena kekhasan dan keenakan lemang produksi masyarakatnya.
} 
malamang ini tidak luput dari kecenderungan atau pergeseran pola pikir masyarakat sekarang yang ingin serba instan (mudah), dilain mana proses pembuatan lamang memang memerlukan waktu yang relatif lama, dan tenaga ekstra.

Fakta bahwa tradisi malamang mulai dilupakan oleh masyarakat Minangkabau sekarang ini, tidak bisa terelakkan. Padahal, sebagai sebuah tradisi tentunya memiliki fungsi sosial dan nilai budaya yang patut dilestarikan dan dipedomani oleh generasi muda sekarang. Jika tidak ada upaya pendokumentasian dan pelestarian, niscaya tradisi ini akan semakin tergerus menjadi nostalgia masa lalu orang Minangkabau. Sehubungan dengan itu, tulisan ini berusaha menelusuri dan mengetahui lebih jauh tentang tradisi malamang dalam kehidupan masyarakat Minangkaba. Pengungkapan hal tersebut akan memberikan pemahaman yang lebih mendalam dan komprehensif tentang tradisi malamang dalam kehidupan masyarakat Minangkabau.

Perlunya kajian ini didasarkan pada pemikiran bahwa setiap masyarakat (suku bangsa), sebagaimana diketahui, memiliki seperangkat aturan yang mengatur pola kehidupannya seharihari atau yang lazim dikenal sebagai kebudayaan. Kebudayaan adalah keseluruhan sistem gagasan, tindakan dan hasil karya manusia dalam rangka kehidupan masyarakat yang dijadikan milik diri manusia dengan belajar (Koentjaraningrat, 1979: 193). Kebudayaan merupakan keseluruhan yang kompleks, yang didalamnya terkandung pengetahuan, kepercayaan, kesenian, moral, hukum, adat istiadat, dan kemampuan-kemampuan lain yang didapat seseorang sebagai anggota masyarakat. Kebudayaan dapat dipisahkan dalam tiga wujud yakni pengetahuan budaya (ide, gagasan), tingkah laku (aktifitas) dan budaya materi atau fisik. Ketiga wujud kebudayaan itu pada dasarnya saling berkaitan dan merupakan perwujudan dari cipta karsa manusia sebagai makhluk budaya yang diwarisi dari generasi sebelumnya. Melville J. Herskovits dan Bronislaw Malinowski (dalam Koentjaraningrat, 1979) mengemukakan bahwa segala sesuatu yang terdapat dalam masyarakat ditentukan oleh kebudayaan yang dimiliki oleh masyarakat itu sendiri. Herskovits memandang kebudayaan sebagai sesuatu yang turun temurun dari satu generasi ke generasi yang lain, yang kemudian disebut sebagai superorganic. Kebudayaan mengandung keseluruhan pengertian, nilai, norma, ilmu pengetahuan serta keseluruhan struktur-struktur sosial, religius, dan lain-lain, tambahan lagi segala pernyataan intelektual dan artistik yang menjadi ciri khas suatu masyarakat.

Salah satu dari wujud kebudayaan itu yakni wujud tingkah laku (aktifitas), diantaranya tercermin dari aktifitas atau kebiasaan tradisional dalam setiap masyarakat yang diwariskan secara turun temurun, yang timbul dari konsepsi budaya masyarakat bersangkutan. Kebiasaan suatu masyarakat yang diwarisi dari generasi sebelumnya lazim juga disebut dengan tradisi 
(tradition). Secara umum, tradisi dianggap sebagai suatu kebiasaan dari kelompok masyarakat pendukung kebudayaan yang penyebaran dan pewarisannya secara turun temurun. Dalam Kamus Besar Bahasa Indonesia diartikan sebagai kebiasaan turun temurun yang masih dijalankan dalam masyarakat. Dalam ilmu Antropologi, tradisi merujuk pada pola-pola kepercayaan, adat istiadat, nilai-nilai, tingkah laku dan pengetahuan atau keahlian yang diwariskan dari generasi ke generasi melalui proses sosialisasi dalam populasi tertentu (Riawanti, 2003; 4). Istilah tradisi kadangkadang digunakan sebagai padanan bagi istilah kebudayaan khususnya mengenai "kebudayaan tradisoinal sehari-hari' atau "kebudayaan rakyat" (folk culture). Hal yang paling mendasar dari tradisi adalah adanya informasi yang diteruskan dari generasi ke generasi baik tertulis maupun (sering kali) lisan, karena tanpa adanya ini, suatu tradisi dapat punah.

Bertitik tolak dari hal diatas, difahami bahwa suatu tradisi berhubungan dengan kebiasaan pada suatu komunitas (masyarakat) yang telah berlangsung sejak lama (turun temurun) dan berkaitan dengan aktifitas bersama masyarakat. Tradisi atau kebiasaan tersebut pada dasarnya merupakan cerminan budaya masyarakatnya yang dipelajari dan diwariskan pada generasi selanjutnya. Keberadaan tradisi itu sekaligus memperkuat persatuan dan kesatuan komunitas tersebut, yang dalam kehidupan sehari-hari saling membantu agar suatu pekerjaan dapat diselesaikan dengan baik dan cepat. Suatu tradisi pada hakikatnya mempunyai peran dan fungsi nilai budaya dalam kehidupan manusia, yang menjadi acuan bagi masyarakat untuk bertingkah laku sesuai kebudayaan yang diembannya. Ahimsa Putra (2007), menyebutkan beberapa ciriciri dari kandungan nilai budaya (tradisi) yakni 1) Tidak terlihat (abstrak), 2) Bersifat sosial (dimiliki bersama), 3) Mempunyai “inti” (core value), 4) Diyakini kebenaran dan kebalikannya, 5) Terkait erat dengan perasaan, dan 6) Relatif tidak berubah. Sedangkan beberapa fungsi nilai budaya adalah sebagai 1) Pedoman umum penilaian, 2) Pedoman umum menafsir, 3) Memahami dan menjelaskan, sebagai pedoman berperilaku dan bertindak, dan 4) Dasar umum bagi norma dan aturan.

Berkaitan dengan makanan tradisional, pada setiap masyarakat pada dasarnya tidak bisa dilepaskan dari budaya lokal sebagai acuan dan mendasari cara pembuatan dan keterlibatan warga suatu kerabat. Makanan tradisional, menurut Kamus Umum Bahasa Indonesia (1976: 1088) adalah segala sesuatu yang dikonsumsi masyarakat suatu daerah secara turun temurun guna memenuhi kebutuhan nutrisi bagi tubuhnya. Ernayanti (2003: 2) memberikan pengertian tentang makanan tradisional memiliki nilai budaya, tradisi, serta kepercayaan yang bersumber dari budaya lokal (local indigenous). Dananjaya (1991;182) menyebutkan bahwa dari sudut ilmu Antropologi atau folklor, makanan merupakan fenomena kebudayaan, oleh karena itu 
makan bukanlah sekedar produksi organism dengan kualitas-kualitas biokimia, yang dapat dikonsumsi oleh organisasi hidup, termasuk juga untuk mempertahankan hidup mereka, melainkan anggota suatu kolektif, makanan selalu ditentukan oleh kebudayaan masing-masing. Ditambahkannya bahwa makanan mempunyai arti simbolik, dalam arti memiliki arti sosial, agama dan lain-lain, serta tergolong folklor bukan lisan. Menurut Dananjaya (1991; 189), upaya menelusuri atau mengkaji makanan (tradisional) suatu kelompok (suku bangsa dan lain-lain) tidak boleh melepaskannya dari konteks kebudayaan atau masyarakatnya. Dengan jalan memperhatikan cara pengolahannya, cara penyajiannya, fungsi makanan di dalam kebudayaan dan masyarakatnya dan lain-lain. Artinya, makanan jelas penting untuk kehidupan biologis, namun ia juga penting demi hubungan sosial. Foster dan Anderson (dlm Dananjaya, 1991; 187188), menyebutkan bahwa secara simbolis makanan sedikitnya dapat berupa empat ungkapan yakni a) Ikatan sosial, b) Solidaritas kelompok, c) Makanan dan ketegangan jiwa, dan d) Simbolisme makanan dalam bahasa. Hal itu menunjukkan bahwa makanan tradisional (adat) mengandung aspek memperkuat ikatan sosial dan solidaritas sosial dalam kehidupan masyarakat pengembannya. Makanan yang tergolong makanan tradisional adalah segala sesuatu yang dikonsumsi masyarakat suatu daerah secara turun temurun. Makanan tradisional itu memiliki nilai budaya, tradisi serta kepercayaan yang bersumber dari budaya lokal (local indigenous). Makanan tradisional suatu daerah bisa menjadi cermin paradaban dan budaya suatu daerah, akan tepat disuguhkan serta dinikmati oleh masyarakat itu pula (Ernayanti, 2003; 16).

Dalam konteks lamang (lemang) pada masyarakat Minangkabau, tentunya tidak bisa dilepaskan dari kebudayaan Minangkabau, karena tradisi malamang merupakan ekspresi masyarakat Minangkabau terhadap bentuk pemenuhan biologis dan hubungan sosial sesama mereka, baik dalam lingkup kerabat maupun masyarakat yang lebih luas. Tradisi malamang semakin memperkuat ikatan kekerabatan, solidaritas dan simbol antara orang-orang yang sekerabat, dan terkait dengan folk culture nya yakni budaya Minangkabau.

\section{METODE PENELITIAN}

Kajian tentang lamang dan tradisi malamang pada masyarakat Minangkabau, didasarkan dari penelitian yang dilakukan di Kecamatan Sintuk Toboh Gadang Kabupaten Padang Pariaman yang terdiri dari 2 (dua) nagari yakni Nagari Sintuk dan Nagari Toboh Gadang. Pemilihan daerah tersebut didasarkan pada kenyataan bahwa sebagian masyarakatnya sekarang ini masih melaksanakan tradisi malamang dalam kehidupan sehari-harinya, ketika menjelang bulan puasa (Ramadhan), lebaran, maulud nabi, dan lainnya. 
Metode atau pendekatan yang digunakan untuk mendapatkan data tentang tradidi malamang adalah metode/pendekatan kualitatif yang lazim digunakan dalam penelitian kebudayaan, yang bertujuan untuk mendapatkan data yang lebih banyak dan mendalam. Dari sifatnya, merupakan penelitian deskriptif analisis untuk menggambarkan tradisi malamang sebagai realitas sosial pada masyarakat Minangkabau, dengan menggunakan beberapa teknik yang lazim dipakai dalam penelitian kualitatif yakni studi kepustakaan, wawancara dan observasi di lapangan. Realisasi penggunaan teknik pengumpulan data tersebut sebagai berikut:

a. Studi Kepustakaan, dengan mengumpulkan artikel, buku, ataupun tulisan-tulisan yang memberikan informasi tentang sumber-sumber tertulis yang berhubungan dengan tradisi malamang pada masyarakat Minangkabau. Studi kepustakaan ditemukan gambaran awal tentang tradisi malamang dan budaya masyarakat pengembannya.

b. Wawancara, dilakukan secara terfokus untuk mendapatkan data dan informasi yang diperlukan, yang dilakukan terhadap informan terpilih (tokoh masyarakat, petani, generasi muda dan lainnya) untuk menggali data yang dibutuhkan. Hasil wawancara ini dianalisa dan dibandingkan dengan data yang diperoleh dari studi kepustakaan untuk memperoleh kelogisan data. (diperbaiki)

c. Pengamatan (observation), diperlukan untuk mengetahui peralatan dan cara pembuatan lamang, kondisi lingkungan sosial, lingkungan alam, dan lainnya. Pengamatan menjadi penting untuk membandingkan antara data wawancara dengan fakta di lapangan. (diperbaiki)

Selanjutnya data dan informasi yang didapat diolah, dianalisa dan dideskripsikan dalam bentuk laporan (dokumentasi) tentang tradisi malamang pada masyarakat Minangkabau.

\section{PEMBAHASAN}

\section{Sekilas Daerah Sintuk Toboh Gadang}

Kecamatan Sintuk Toboh Gadang merupakan salah satu kecamatan di Kabupaten Padang Pariaman, yang baru terbentuk tahun 1995 dan merupakan pemekaran dari Kecamatan Lubuk Alung Kabupaten Padang Pariaman. Kecamatan ini terdiri dari dua nagari yaitu Nagari Sintuk dan Nagari Toboh Gadang yang bertetangga, dan secara budaya memiliki banyak kesamaan dalam kebiasaan sehari-hari. Berdasarkan cerita turun temurun yang diwarisi oleh masyarakat 
Sintuk, daerah tersebut merupakan kawasan pertama yang dihuni di Kecamatan Sintuk Toboh Gadang, sedangkan Toboh Gadang merupakan wilayah perluasan dari Sintuk. Cerita yang berkembang di tengah masyarakat menyebutkan bahwa di Sintuk dulu terdapat sebuah batang kayu yang sangat besar dan tinggi, kayu ini berfungsi sebagai penanda bagi seluruh masyarakat yang sedang melakukan perjalanan.

Nagari Toboh Gadang merupakan sebuah nagari yang unik, hal ini terlihat dari nama korong yang terdapat di nagari ini yang diawali dengan kata "toboh”. Berdasarkan informasi dan cerita yang berkembang, toboh berasal dari bahasa lama yang memiliki pengertian kelompok. Hal ini yang mendorong seluruh korong di Toboh Gadang mengunakan kata "toboh" yang diikuti dengan nama daerah, seperti Toboh Tangah Padang yang memiliki pengertian kelompok masyarakat yang tinggal ditengah Padang, sedangkan Toboh Gadang memiliki pengertian sebagai kumpulan dari seluruh toboh yang terdapat dikawasan itu³.

\section{Lamang}

Sebagaimana telah diungkapkan, lamang adalah sejenis makanan khas masyarakat Minangkabau yang terbuat dari beras puluik (ketan) dengan wadah dari bambu (talang, buluh). Jenis dan varian dari lamang cukup banyak, walaupun proses pembuatan dan bahan yang digunakan hampir sama, yang membedakan hanyalah bahan dasar. Lamang yang dibuat dari beras ketan lazim disebut dengan lamang bareh katan (lemang beras ketan) atau lamang sipuluik. Lainnya adalah lamang baluo, lamang pisang, lamang kuning, lamang ubi jalar, lamang labu, lamang ubi kayu, lamang durian dan lamang jagung. Namun yang menonjol dan banyak dibuat oleh masyarakat Minangkabau adalah lamang dari bahan puluik (ketan) atau lamang sipuluik. Biasanya lamang ini dilengkapi dengan tapai sebagai pelengkapnya, sehingga dikenal dengan sebutan lamang tapai. Berikut ini diuraikan jenis lamang yang terdapat dalam kehidupam masyarakat Minangkabau dan bahan yang digunakan.

\footnotetext{
${ }^{3}$ Pengertian Padang di Minangkabau adalah sebuah lapangan/darah yang luas, disamping menjadi nama pada beberapa daerah.
} 


\section{Jenis-jenis Lamang}

a) Lamang Puluik

Lamang puluik adalah lamang yang menjadikan beras puluik sebagai bahan dasar, dan merupakan lamang yang paling banyak diproduksi di Minangkabau. Proses pembuatan lamang puluik adalah memasukan beras puluik ke dalam talang (buluh). Setelah itu talang yang sudah berisi puluik ketan dalam wadah bambu (talang) dibawa ke tengah lata (latar), dan kemudian dimasak selama 6 jam, untuk memberi rasa lebih nikmat di dalam santan dimasukan garam dan kemiri.

\section{b) Lamang Pisang}

Lamang pisang adalah lamang yang mencampurkan pisang dan puluik dalam proses pembuatannya. Proses pembuatan tidak berbeda dengan lamang puluik, dan yang membedakan adalah beras puluik dan santan dicampur terlebih dahulu sebelum dimasukkan ke dalam talang. Proses selanjutnya sama dengan pembuatan lamang puluik.

\section{c) Lamang Kuning}

Lamang kuning adalah jenis lamang dengan tepung beras dan kunyit sebagai bahan utama. Lamang ini dibuat dengan menggiling beras sehingga berbentuk tepung, yang kemudian dicampur dengan kunyit, lalu dimasak seperti lamang lainnya. Rasa dan aroma yang dihasilkan oleh lamang kuning sangat menjanjikan atau enak untuk disantap bersama. Bahan yang digunakan untuk pembuatan selain adalah tepung beras dan kunyit adalah santan, dan garam. Semua bahan ini terlebih dahulu diaduk diluar, setelah itu baru dimasukkan kedalam talang, baru dibakar di lata (latar).

\section{d) Lamang Ubi}

Lamang ubi adalah lamang dengan ubi kayu sebagai bahan dasar dalam pembuatannya. Lamang ini dibuat dengan mencampurkan saka dengan ubi sebelum dimasukkan kedalam talang, dan proses pembuatannya hampir sama dengan lamang jenis lainnya. Bahan yang digunakan adalah ubi, saka, dan garam yang diaduk lalu sebelum dimasukkan ke dalam talang. Dalam pembuatan lamang ubi tidak dibutuhkan santan kelapa, sebagaimana pembuatan lamang jenis lainnya. 


\section{Bahan/kelengkapan}

Beberapa bahan yang digunakan dalam proses pembuatan lamang menjadi makanan yang siap untuk disantap, yakni;

\section{a) Talang/Bambu}

Talang (bambu) merupakan wadah yang memanfaatkan satu ruang dari pohon bambu dengan ukuran yang beragam, tergantung kemauan pembuatnya. ${ }^{4}$ Bambu jens ini juga dimanfaatkan oleh penduduk untuk mengambil rebungnya untuk kelengkapan pembuatan gulai rebung yang merupakan makanan khas masyarakat Minangkabau.

\section{b) Santan}

Santan adalah saripati dari buah kelapa, dan kualitasnya sangat ditentukan oleh buah kelapa yang dipilih untuk dijadikan santan. Umumnya buah kelapa yang dipilih untuk dijadikan bahan lamang adalah kelapa yang kalapo/parampingan. ${ }^{5}$.

\section{c) Beras Puluik (ketan)}

Beras puluik (ketat) terbuat dari padi puluik, yang terdiri dari 2 (dua) yakni padi putih dan padi ungu (kehitaman), dan yang banyak dipakai adalah beras puluik putih yang menyerupai beras padi biasa. Apabila dimasak atau di kukus, puluik berubah warnanya menjadi lebih jernih dan sangat melekit dibanding dengan beras biasa ${ }^{6}$.

\footnotetext{
${ }^{4}$ Talang termasuk dalam kelompok bambu dan merupakan salah satu tumbuhan daerah tropis dan subtropik Talang, termasuk dalam devisi spermatophyta, subdevisi angiospermae, klas monocotyledonae, ordo Graminales, family graminiae, sub family bamusoideae. Secara alami talang dapat tumbuh pada hutan primer maupun hutan skunder (bekas perladangan dan belukar). Bambu jenis juga dimanfaatkan oleh penduduk untuk diambil rebung yang dimanfaatkan untuk menjadi bahan makanan.

${ }^{5}$ Kelapa merupakan tanaman perkebunan/industri berupa pohon batang lurus dari famili Palmae. Ada dua pendapat mengenai asal usul kelapa yaitu dari Amerika Selatan menurut D.F. Cook, Van Martius Beccari dan Thor Herjerdahl dan dari Asia atau Indo Pasific menurut Berry, Werth, Mearil, Mayurathan, Lepesma, dan Pureseglove. Kata coco pertama kali digunakan oleh Vasco da Gama, atau dapat juga disebut nux indica, al djanz al kindi, ganz-ganz, nargil, narlie, tenga, temuai. Daun muda dipergunakan sebagai pembungkus ketupat dan sebagai bahan baku obat tradisional, daun tua dapat diayam dan dipergunakan sebagai atap, sedang lidinya sebagai bahan pembuat sapu lidi. Batang kelapa dapat digunakan sebagai bahan baku perabotan, mebel/furniture atau bahan bangunan dan jembatan darurat. Akar kelapa dapat digunakan sebagai bahan baku pembuatan bir, atau bahan baku pembuatan zat warna. coconut, dan pohon kehidupan. Tanaman kelapa (Cocos nucifera L) merupakan tanaman serbaguna atau tanaman yang mempunyai nilai ekonomi tinggi. Seluruh bagian pohon kelapa dapat dimanfaatkan untuk kepentingan manusia, sehingga pohon ini sering disebut pohon kehidupan (tree of life) karena hampir seluruh bagian dari pohon, akar, batang, daun dan buahnya dapat dipergunakan untuk kebutuhan kehidupan manusia sehari-hari. Dalam pembuatan lamang buah kelapa yang diambil adalah bagian dalamnya atau dikenal dengan nama isinya.

${ }^{6}$ Pulut putih melekit karena mengandung 2 jenis bahan kanji yang tinggi, yaitu "amylase" dan "amylopectin." Kandungan amylase amat sedikit, tetapi kandungan amylopectin amat tinggi. Amylopectin ini yang menyebabkan pulut putih bersifat melekit.
} 


\section{d) Pucuk Daun Pisang}

Daun pisang merupakan salah satu komponen penting dalam pembuatan lamang, yang berfungsi sebagai alas talang, sehingga daun pisang beras puluik terpisahkan dengan batang lamang. Daun pisang terbaik untuk pembuatan lamang adalah pisang batu disebabkan jauh lebih tahan jika dipanaskan, dibanding dengan daun pisang lain yang jika dipanaskan mudah pecah, sehingga dikhawatirkan ketika memasak lamang, beras puluik bisa keluar dan menempel ke batang talang. Daun pisang berfungsi untuk melapisi dinding bambu supaya beras yang dimasukkan ke dalam ruas talang (bambu) itu tidak terkena serbuk yang melekat di dinding bambu tersebut.

\section{e) Garam dan Kemiri}

Garam adalah pemberi rasa dalam proses pembuatan lamang, dan biasa digunakan adalah garam halus atau garam kasar. Garam dimasukkan bersama dengan santan untuk mempermudah menyebarnya garam dalam seluruh batang lamang. Sedangkan kemiri dibutuhkan untuk mempermudah berpisahnya beras puluik dengan batang talang. Kemiri sangat dibutuhkan sebab bentuk lamang yang dihasilkan akan terjamin jika memakai kemiri. Andaikata pembuatan lamang tidak menggunakan kemiri, lamang yang dihasilkan kurang bagus sebab beras puluik dan talang sulit untuk dipisahkan alias lengket.

\section{Proses Pembuatan Lamang}

Pembuatan lamang pada umumnya hampir sama dimana-mana, yang membedakan adalah bahan dasar dan jenis lamang yang akan dibuat. Proses pembuatan lamang sangatlah lama, dihitung dari proses mencari talang membutuhkan waktu paling cepat 2 (dua) hari. Jika dihitung dari proses pengolahan membutuhkan waktu satu hari, dan untuk memasak lamang perlu waktu lebih kurang 6 jam. Berikut tahap-tahap dalam pembuatan lamang :

\section{a) Mencari Talang}

Mencari talang merupakan langkah pertama yang dilakukan oleh setiap orang yang akan membuat lamang. ${ }^{7}$ Talang yang digunakan untuk pembuatan lamang adalah talang dari segi umur tidak terlalu tua atau muda. Jika terlalu tua, talang telah menjadi keras, sedangkan

\footnotetext{
${ }^{7}$ Dahulu setiap kaum mempunyai rumpun talang, yang dimanfaatkan setiap anggota keluarga dalam kaum tersebut.
} 
jika terlalu muda, talang mudah pecah (retak) sehingga dikhawatirkan akan merusak hasil lamang. Kondisi ini menyebabkan pembuat lamang mesti mencari talang terbaik dari sekumpulan pohon talang (bambu). Setelah ditemukan talang terbaik lalu di potong dan dibersihkan. Pada masa dahulu, ada orang yang menjual atau menjajakan talang ke kampungkampung, sehingga tidak perlu lagi mencarinya ke hutan atau pokok bambu. ${ }^{8}$

\section{b) Memotong Talang}

Proses memotong talang ditentukan dari ruas yang dimiliki oleh sebuah talang, semakin banyak ruasnya semakin banyak kesempatan untuk memotong talang menjadi beberapa buah. Pembagian sebuah talang untuk dijadikan sebatang lamang ditentukan dari ruas lamang tersebut. Alat yang digunakan untuk memotong talang pada awalnya adalah parang, dan dalam perkembangan selanjutnya banyak orang lebih suka menggunakan gergaji untuk memotong talang, karena hasilnya lebih rapi dan bagus.

\section{c) Membersihkan Talang}

Talang merupakan tumbuhan yang memiliki miang yang bisa memberikan rasa gatal pada kulit ketika bersentuhan dengan miang tersebut. Oleh karena itu setiap orang akan memasak lamang, akan mencuci talang tersebut sampai bersih agar miang yang terdapat di batang talang hilang. Mencuci talang juga bertujuan untuk membersihkan kotoran yang mungkin terdapat didalam talang akibat proses pemotongan yang dilakukan. Talang yang sudah bersih tersebut diletakkan di sudut rumah dan siap untuk digunakan sebagai wadah untuk pembuatan lamang.

\section{d) Mencari Pucuk Daun Pisang}

Pucuk daun pisang merupakan salah satu komponen penting dalam pembuatan lamang, karena pucuk daun pisang berfungsi untuk melapisi bagian dalam talang dan memberikan rasa enak pada lamang. Pucuk daun pisang terbaik yang bisa digunakan untuk pembuatan lamang adalah pucuk daun pisang batu, sebab pucuk daun pisang batu lebih kuat ketika dipanaskan. Pucuk daun pisang yang baru diambil selanjutnya dibersihkan, kemudian dipotong dan diolah sedemikian rupa sehingga bisa dimasukkan ke dalam talang. Cara pengolahannya adalah pucuk daun pisang dibuat menyerupai bagian dalam talang dengan menggunakan batang daun pisang

\footnotetext{
${ }^{8}$ Di Nagari Limokaum Kabupaten Tanah Datar, talang yang telah siap pakai berasal dari Nagari Sawah Tangah, Kecamatan Pariangan, yang khusus mengolah ruas bambu menjadi talang. Dahulu, hal yang biasa ditemui kala itu, seorang laki-laki membawa banyak talang yang dijunjung di kepalanya.
} 
sebagai alat pembuat bulatan. Di bagian ujung daun pisang biasanya diletakkan daun pandan yang berfungsi untuk memberi aroma pada lamang.

\section{e) Mengalas Talang dengan Daun Pisang}

Pucuk daun pisang yang telah dibentuk menyerupai bagian dalam lamang, dimasukkan kedalam talang yang fungsinya adalah untuk menghindari puluik menempel ke batang talang. Disamping itu memberikan kesan rapi dan enak dari lamang tersebut, dan membentuk body lamang yang seukuran ruang ruas bambu (talang)..

\section{f) Membersihkan dan Mengeringkan Beras Puluik}

Proses selanjutnya dalam pembuatan lamang adalah membersihkan beras puluik dari kotoran yang mungkin terdapat dalam beras puluik tersebut (manampih bareh) yaitu memisahkan antara beras puluik dengan puluik kosong (hampa) yang mungkin terdapat dalam beras puluik. Proses ini tidak berlangsung lama sebab beras puluik yang terdapat hari ini kebanyakkan telah dibersihkan sebelum diperjualbelikan. Setelah proses manampih bareh, dilanjutkan dengan membersihkan beras dari debu dan kotoran yang melekat dalam beras (mambasuh bareh), untuk memberi jaminan bahwa beras yang akan dimasukkan ke dalam talang betul-betul telah bersih, sehingga memberikan rasa aman ketika lamang dikonsumsi nantinya. Beras yang telah dicuci kemudian dikeringkan supaya kadar air yang terdapat dalam beras puluik bisa berkurang, sehingga santan kelapa bisa meresap dengan baik ke dalam puluik.

\section{g) Memasukkan Beras ke dalam Talang}

Beras puluik yang telah dikeringkan, dimasukkan ke dalam talang yang telah dialas dengan daun pisang. Banyaknya beras puluik yang akan dimasukkan kedalam talang ditentukan oleh besar dan panjang talang yang digunakan. Umumnya satu batang talang menghabiskan 1$1 \frac{1}{2}$ liter beras puluik. Proses memasukkan beras puluik ke dalam batang talang akan dihentikan ketika beras puluik telah mencapai $3 / 4$ dari tingginya batang talang.

\section{h) Membuka dan Mengkukur Kelapa}

Membuka kelapa adalah memisahkan antara kulit kelapa dan bagian dalam yang siap untuk dikukur atau mengambil bagian dalam buah kelapa. Proses membuka kelapa sesungguhnya dilakukan bersamaan dengan proses membersihkan beras puluik, sebab pekerjaan membuat lamang tidak bisa dikerjakan oleh satu orang namun melibatkan beberapa orang. Semakin banyak orang yang terlibat semakin cepatlah proses pekerjaan membuat lamang. Selanjutnya mengkukur 
kelapa atau kegiatan memisahkan bagian isi kelapa dengan batok kelapa (tempurung). Pada awalnya proses mengkukur kelapa dilakukan dengan menggunakan kukuran yaitu sepotong besi yang diberi mata pada bagian ujung yang berbentuk seperti pisau yang akan mengikis isi kelapa sehingga yang tersisa hanya tempurung (batok kelapa). Dalam perkembangan selanjutnya, orang lebih menggunakan tenaga mesin untuk memisahkan isi kelapa dari batok kelapa. Hasil dari mengkukur kelapa dikenal dengan karambie yang siap diolah menjadi santan. Proses pembuatan santan dimulai dari membuka buah kelapa, dilanjutkan dengan memisahkan isi buah kelapa dengan batok kelapa, proses ini dikenal dengan nama mangukue karambie (mengkukur kelapa).

\section{i) Marameh Kerambie jadi Santan}

Setelah mangukue karambie (mengkukur kelapa), dilanjutkan dengan meremas atau memberikan tekanan kepada isi kelapa sehingga mengeluarkan air yang terdapat di dalamnya, dikenal dengan nama saripati kelapa (santan). Proses pembuatan santan itu terdiri dari beberapa tahap, pertama adalah kerambie diperas tidak menggunakan air sehingga yang dihasilkan adalah santan murni dengan kualitas terbaik. Setelah itu kerambie tadi ditambah dengan sedikit air dan terus berlanjut sampai kerambie dipandang tidak lagi memiliki santan. Untuk menjaga kualitas santan bersih tidak tercampur dengan kerambie, biasanya digunakan tapisan (saringan) atau kain putih yang bersih untuk menjaga kualitas santan. Proses mengeluarkan dan meremas kelapa dilanjutkan dengan mencampur air ke dalam isi kelapa dan berlanjut sampai isi kelapa tidak lagi menghasilkan santan yang baik. Santan yang dibutuhkan dalam pembuatan lamang adalah saripati kelapa, sebab semakin bagus kualitas santan semakin enaklah lamang yang akan dihasilkan.

\section{j) Memasukkan Santan ke dalam Talang}

Proses pembuatan lamang dilanjutkan dengan memasukkan santan ke dalam talang yang telah diisi dengan beras puluik. Untuk menghasilkan lamang yang baik, santan yang dimasukkan sampai puluik terbenam sebab jika tidak maka kualitas dari lamang menjadi kurang baik. Proses memasukkan santan ke dalam talang juga dilakukan ketika lamang telah sampai di lata (latar) atau tempat pembakaran. Alasan utama yang menyebabkan santan ditambah adalah ketika beras puluik yang dimasukkan ternyata berlebih sehingga keluar dari dalam talang dan mendorong santan untuk terbuang keluar. 


\section{k) Membuat Latar}

Latar (lata) adalah tempat pembakaran talang sehingga bisa menghasilkan lamang. Proses pembakaran yang begitu lama kira-kira 6 jam, menyebabkan lata (latar) yang akan dibuat harus disusun dengan baik sehingga bisa menjamin ketersediaan api dalam proses pembakaran talang. Lata (latar) terbuat dari dua buah batang besi atau kayu sebagai tiang yang disusun saling berhadapan. Ditengah-tengah batang besi disusun perapian yang terdiri dari kayu bakar besar yang diletakkan pada bagian bawah, ditambah dengan tempurung dan sabuik (sabut). Komposisi ini menyebabkan ketersediaan api (bara) menjadi lebih terjamin sampai lamang itu masak. Lokasi yang dipilih untuk membuat lata (latar) adalah tanah lapang (luas) yang terbuka dengan tujuan mempermudah menjaga bara (baro) api. Selama proses pembakaran bara (api) dijaga tidak boleh padami, jika mati dikhawatirkan akan merusak kualitas lamang.

\section{l) Membawa Talang ke Latar}

Proses pembuatan lamang dilanjutkan dengan membawa talang yang telah diisi beras puluik dan santan ke lata (latar) dan siap untuk dimasak pada tempat yang telah diisediakan. Talang yang telah berisi beras puluik dan santan itu disusun berjejer dengan disandarkan pada kayu yang dilintangkan diatas kedua tiangnya. Diusahakan agar talang atau bambu tidak bisa kena api perapian yang telah disiapkan dalam sebuah lubang untuk menghangatkan lamang hingga masak.

\section{m) Membakar / Memasak Lamang}

Membakar/memasak lamang adalah proses mematangkan atau merubah beras puluik menjadi makanan lamang. Proses ini membutuhkan waktu yang paling lama dalam pembuatan lamang dan membutuhkan keahlian tersediri. Mulai dari cara membuat api untuk membakar lamang, jika api terlalu besar maka talang akan cepat hangus sedangkan beras puluik yang terdapat di dalam talang belum matang sehingga lamang yang dihasilkan menjadi kurang baik. Di samping itu dalam proses memasak lamang, talang harus dibolak-balik sehingga api/bara yang dihasilkan oleh lata (latar) bisa menyentuh semua sisi yang terdapat di talang. Untuk menjaga agar talang tidak hangus terbakar maka jarak antara talang dengan api paling kurang $1 / 2$ meter, sehingga proses memasak lamang bukan lewat pembakaran tapi lewat hawa hangat yang dihasilkan oleh api . 


\section{Tradisi Malamang}

\section{Latar Belakang/Asal Usul}

Munculnya tradisi malamang, sebagaimana telah diungkapkan, tidak dapat dilepaskan dengan muncul dan berkembangnya agama Islam di Minangkabau sekitar tiga ratus tahun yang lalu. Saat itu ulama terkenal Syekh Burhanuddin datang ke daerah pesisir Minangkabau untuk menyiarkan agama Islam, terutama bertempat di Ulakan, Pariaman. Menurut tambo, Syech Burhanuddin rajin berkunjung ke rumah-rumah penduduk untuk bersilaturrahmi dan menyiarkan agama Islam, dan oleh masyarakat disuguhi makanan saat bertamu tersebut. Walaupun Islam sudah mulai berkembang namun masih tetap tidak tahu halal dan haram, masyarakat tetap masih memakan makanan yang haram tersebut. Jamuan makan dihidangkan adalah gulai babi, rendang tikus dan goreng ular, sehingga Syekh Burhanuddin meragukan kehalalan makanan yang dihidangkan. Ketika dipersilahkan untuk memakan makanan yang telah telah tersedia., Syekh Burhanuddin pun menjawab dengan lemah lembut bahwa beliau tidak suka gulai babi, rendang tikus dan goreng ular.

Kebiasaan penduduk saat itu yang masih memakan makanan yang terlarang dalam agama Islam menyebabkan Syekh Burhanuddin memperkenalkan cara memasak yang bisa dipastikan tidak akan tercampur antara yang halal dan yang haram. Syekh Burhanuddin memasak nasi dalam ruas talang (bambu) yang belum tersentuh oleh siapapun. Talang atau bambu tipis ini dilapisi dengan daun pisang yang berfungsi untuk melapisi dinding bambu supaya beras yang dimasukkan kedalam ruas bambu itu tidak terkena serbuk yang melekat di dinding bambu tersebut. Setelah masak nasi dari bambu ini barulah Syekh Burhanuddin makan dengan hati yang tenang. Awalnya Syekh Burhanuddin menggunakan beras biasa namun karena tidak tahan lama dan cepat basi maka beliau menggantinya dengan beras ketan (puluik) yang bisa lebih tahan lama. Disamping itu, memasak beras biasa berbeda dengan beras ketan, karena beras ketan lebih lama masaknya. Saat memasak beras ketan, talang (bambu) diputar-putar agar merata, dan kemudian dimasak dengan menggunakan tungku pembakaran yang menggunakan kayu bakar.. Seiring berjalannya waktu, makanan beras ketan dalam talang (bambu) ini disebutlah namanya dengan istilah lamang. Proses memasak seperti ini ditiru oleh masyarakat sekitar setelah melihat dan mendengarkan penjelasan Syekh Burhanuddin. Kaitan keberadaan lamang dengan Syech Burhanuddin, menyebabkan lamang tetap eksis dalam kehidupan masyarakat di 
Pariaman, sebab tradisi dan prilaku masyarakat Pariaman dalam beribadah selalu dikaitkan dengan Syech Burhanuddin. Hal ini yang menyebabkan lamang masih tetap eksis di Padang Pariaman sekarang ini, sedangkan di daerah lain lamang telah mulai dilupakan atau tergantikan.

Tradisi malamang selanjutnya terus berkembang hingga ke seluruh daerah Minangkabau. Orang Minangkabau yang terkenal dengan tradisi merantau dan berdagang ikut membantu menyebarluaskan tradisi malamang, sehingga lamang juga dikenal di daerah-daerah lain di Indonesia hingga sampai ke luar negeri.

\section{Waktu Malamang}

Tradisi malamang pada masyarakat Minangkabau, diselenggarakan pada waktu-waktu tertentu namun biasanya pada waktu peringatan Maulud Nabi, menjelang bulan puasa (Ramadhan), menjelang lebaran haji (Idul Adha), peringatan kamatian, dan lainnya. Di Nagari Limokaum Kabupaten Tanah Datar, dahulunya tradisi malamang selalu diadakan menjelang lebaran haji (Idul Adha). Setiap rumah akan membuat lamang sehari menjelang lebaran haji untuk dinikmati pada hari lebaran (sesudah shalat) dan untuk diantar kerumah mertua dan keluarga lainnya, serta tamu yang datang ke rumah berlebaran. Hanya saja, tradisi itu boleh dikatakan telah hilang dan tinggal kenangan. Tradisi malamang pada waktu peringatan kematian terdapat pada masyarakat di daerah Pariaman, Solok dan daerah lainnya.

Tradisi malamang untuk masa sekarang, sebagaimana telah diungkapkan, masih dilaksanakan dan bisa dilihat di daerah Sintuk Toboh Gadang di Kabupaten Padang Pariaman. Pelaksanaan tradisi malamang oleh masyarakat setempat diadakan ketika merayakan Maulud Nabi, menjelang bulan puasa (Ramadhan) yang biasa disebut sebagai "bulan lamang" atau bulan malamang, peringatan Maulud Nabi, kematian seseorang, Berikut ini diungkapkan bagaimana pelaksanaan tradisi malamang pada masyarakat Sintuk Toboh Gadang.

\section{a) Maulud Nabi}

Maulud Nabi merupakan salah satu hari besar agama Islam yang mendapatkan perhatian lebih oleh masyarakat di Minangkabau khususnya di Sintuk Tobo Gadang Kabupaten Padang Pariaman, dan pada waktu itu masyarakat membuat lamang. Acara peringatan Maulud Nabi pada masyarakat Sintuk Toboh Gadang diawali dari bulan Rabiul Awal sampai dengan Jumadil 
Akhir. Panjangnya waktu yang digunakan oleh masyarakat Sintuk Toboh Gadang dalam melaksanakan acara Maulud Nabi berkaitan dengan tradisi yang telah berlangsung ditengahtengah masyarakat. Aturan adat menjelaskan bahwa setiap surau kaum diwajibkan untuk melaksanakan acara maulud, yang diawali di Masjid Raya nagari, disusul di surau-surau kaum secara bergantian. Pelaksanaan Maulud Nabi di masjid raya masing-masing nagari tepat pada tanggal 12 Rabiul Awal menurut kalender Islam yang disusun oleh orang-orang Syatariah. Masing-masing surau dalam sebuah nagari mendapatkan waktu melaksanakan maulud nabi yang diawali dengan sebuah kegiatan yang dikenal dengan manyongsong maulud (menyambut Maulud). Pada acara ini seluruh pengurus surau kaum mengundang ninik mamak kaum untuk menentukan kapan acara maulud akan dilaksanakan. Di samping ninik mamak, pengurus surau kaum juga mengundang tukang dikia dan urang siak, orang ini bertugas badikia (berzikir) di surau selama rapat berlangsung.

Kesepakatan yang telah dibuat oleh ninik mamak dan pengurus surau, dilaporkan kepada tukang dikia dan kapalo urang siak. Orang inilah yang menentukan apakah pada tanggal yang telah ditetapkan tersebut bisa dilaksanakan acara maulud nabi atau harus pindah, sebab pada tanggal yang sama telah diisi oleh yang lain. Alasan pindah hari, bisa dilakukan kalau pada tanggal yang telah ditetapkan terlalu dekat dengan surau kaum dalam korong yang sama atau terlalu berdekatan dengan acara maulud di surau lain sehingga tukang dikia dan urang siak tidak bisa tampil dengan maksimal. Pemilihan hari menjadi penting sebab acara maulud dilakukan disamping untuk memperingati hari kelahiran Nabi Muhammad SAW, juga bertujuan mengumpulkan uang untuk pembangunan surau kaum dan masjid raya.

Pada bulan Maulud Nabi di Sintuk Toboh Gadang sangat mudah menemukan orang yang membawa lamang dan membuat lamang karena hampir setiap minggu ada saja surau kaum yang mengadakan acara maulud nabi. Secara teknis pelaksanaan maulud nabi di Sintuk Toboh Gadang dilaksanakan dengan semangat kebersamaan dan gotong royong terlihat sangat jelas dalam acara maulud nabi di Masjid Raya Nagari ataupun surau kaum. Dalam acara maulud nabi tingkat nagari, setiap tuangku, labai, bilal dan imam dalam Nagari Sintuk harus membawa juadah dan lamang ke masjid raya. Di samping itu, ada aturan dalam adat yang menjelaskan ada korong yang harus bertanggung jawab membawakan nasi untuk makan malam, Setiap tahunnya, korong yang bertugas untuk memberikan makan tukang dikia dan urang siak selalu 
bergantian. Sedangkan untuk makan siang, seluruh penduduk dalam nagari harus membawa makanan dan lamang paling kurang 2 batang per orang ke masjid raya. Perkembangan selanjutnya memperlihatkan bahwa orang yang membawa makanan ke masjid nagari, biasanya ditetapkan oleh labai pada masing-masing surau kaum. Hal ini terkait erat dengan jumlah penduduk dan banyaknya orang yang datang ke masjid raya untuk makan bersama-sama. Perubahan zaman menyebabkan jumlah orang yang mau makan bersama-sama di dalam masjid menjadi berkurang sehingga banyak juadah yang telah dibawa tidak dimakan oleh peserta Maulud Nabi.

Lamang menjadi salah satu komponen terpenting yang harus disediakan dalam acara maulud nabi di Sintuk Toboh Gadang. pada saat pelaksanaan Maulud Nabi di Masjid Raya, bisa dipastikan seluruh korong yang ada dalam nagari tersebut sedang membuat lamang. Fungsi lamang dalam acara maulud adalah sebagai buah tangan yang akan diberikan oleh pengurus masjid raya dan setiap tamu yang telah datang serta memberikan sumbangan terhadap pembangunan yang akan dilaksanakan oleh masjid raya dan surau. Secara budaya pemberian lamang merupakan simbol dari upaya masyarakat untuk melanjutkan tradisi yang telah turun temurun dilaksanakan. Berdasarkan keyakinan yang mereka percayai bahwa Syech Burhanuddin setiap berdo'a dan berzikir di rumah orang, sebagai buah tangan dari tuan rumah maka diberilah lamang kepada beliau. Hal inilah yang dipertahankan oleh setiap orang di Sintuk Toboh Gadang untuk memberikan lamang sebagai buah tangan bagi tukang dikia dan urang siak yang telah membacakan do'a dan dikia diatas masjid.

Fenomena yang sama sesungguhnya juga ditemukan dalam acara Maulud Nabi yang dilaksanakan di masing-masing surau kaum. Perbedaan utama adalah orang yang membawa juadah ke surau hanyalah anggota kaum dalam surau tersebut. Terbatasnya jumlah orang dalam surau tersebut menyebabkan pengurus surau membuat sebuah panitia khusus yang bertanggung jawab membuat lamang yang akan dibagi pada seluruh tamu yang datang memenuhi undangan. Aturan adat menjelaskan bahwa setiap juadah yang datang didampingi oleh 2 (dua) buah lamang. Pengurus surau berpandangan jumah lamang yang datang ke surau tidak sebanding dengan jumlah tamu maka mereka harus membuat lamang. Maulud nabi yang dilaksanakan di Sintuk Toboh Gadang berlangsung selama semalam se hari, di mulai dari jam 9 malam berakhir jam 4 sore. 
Biasanya proses pembuatan lamang oleh pengurus surau dilaksanakan bersamaan dengan acara maulud nabi. Pada saat orang siak mulai badikia (berzikir) diatas surau maka panitia yang telah ditetapkan tadi mulai bekerja membuat lamang, mulai dari membersihkan talang sampai dengan lamang siap untuk dimasak. Banyaknya jumlah lamang yang akan dimasak menyebabkan waktu dalam pembuatan lamang menjadi lebih lama. Jam 4 pagi, barulah lamang diantar pada tempat pemanggangan (pembakaran), dan setelah menunggu selama 6-8 jam, lamang telah siap untuk diberikan kepada tamu yang hadir. Lamang yang dibuat oleh masingmasing anggota kaum biasanya dikerjakan di setiap rumah. Jumlah yang dibuat oleh masingmasing rumah berbeda, walaupun untuk yang dibawa ke surau untuk setiap rumah jumlahnya sama. Perbedaan ini terkait erat dengan kemampuan sang pemilik rumah dan banyaknya ipar dan besan dalam rumah tersebut. Semakin mampu mereka atau banyaknya jumlah ipar dan besan maka jumlah lamang yang akan dibuat lebih banyak sebab lamang dan juadah yang telah dibuat juga diantar pada ipar dan besan tersebut. Acara Maulud Nabi merupakan media untuk meningkatkan tali silahturahmi antara sanak saudara, ipar dan besan. Fungsi lamang yang dibawa dan dibuat oleh orang surau adalah untuk diberikan kepada setiap tamu dan undangan yang telah datang memenuhi undangan pengurus surau. Banyaknya surau yang melaksanakan acara maulud Nabi di Kecamatan Sintuk Toboh Gadang meperlihatkan bahwa tradisi malamang tetap eksis sampai sekarang ini.

\section{b) Menjelang Ramadhan (Bulan Lamang)}

Masyarakat Pariaman membagi bulan dalam setahun berdasarkan beberapa kelompok bulan seperti bulan maulud, bulan sarang bareh, bulan lamang dan lainnya. Salah satu bulan yang menjadikan lamang sebagai menu utama adalah bulan malamang, yang berlangsung setiap bulan Sya'ban atau sebelum bulan puasa (Ramadhan). Dahulu setiap keluarga akan membuat lamang di masing-masing rumah dengan tujuan untuk diberikan kepada ipar dan besan masingmasing. Pembuatan lamang ini bertujuan untuk meningkatkan tali silaturahmi antara ipar dan besan dalam sebuah keluarga, dan dalam rangka menyambut bulan suci Ramadhan. Jenis lamang yang dibuat oleh masing-masing keluarga tergantung pada kemampuan mereka, namun mayoritas lamang yang dibuat oleh masing-masing rumah adalah lamang katan, lamang pisang dan lamang kuning. Pada bulan lamang (malamang) tidak memiliki aturan tersendiri tentang jenis lamang 
yang harus di buat, pemilihan lamang ini lebih disebabkan oleh karena rasa lamang tersebut bisa diterima oleh siapapun.

Jumlah lamang yang dibuat oleh sebuah keluarga (rumah) pada bulan Lamang ini sesungguhnya juga dipengaruhi oleh kondisi yang terjadi pada keluarga tersebut. Jika, pada sebuah keluarga baru saja berminantu (punya menantu baru) maka jumlah lamang yang dibuat menjadi lebih banyak. Kondisi ini terkait erat dengan aturan adat mewajibkan setiap menantu (perempuan) baru harus mengantar lamang ke rumah setiap mamak dari suaminya. Semakin banyak mamak (saudara perempuan ibu) suami, semakin banyaklah lamang yang harus dibuat oleh keluarga tersebut. Lamang diantar bersama dengan makanan kecil lainnya seperti lapek bugih, onde-onde, agar-agar, goreng dan lain-lain. Perkembangan selanjutnya memperlihatkan jumlah lamang yang harus dibuat menjadi berkurang seiring kewajiban untuk mengantar lamang hanya kepada mertua dan besan sedangkan mamak tidak lagi menjadi kewajiban.

Jenis lamang yang dibuat oleh masing-masing keluarga tergantung pada kemampuan mereka. Mayoritas lamang yang dibuat oleh masing-masing rumah adalah lamang katan, lamang pisang dan lamang kuning. Pada Bulan lamang tidak memiliki aturan tersendiri tentang jenis lamang yang harus di buat, pemilihan lamang ini lebih disebabkan oleh karena rasa lamang tersebut bisa diterima oleh siapapun. Pada bulan ini yang terutama adalah saling memberinya antara besan. Hal itu menggambarkan bahwa lamang juga telah dijadikan sebagai upaya untuk meningkatkan tali silaturahmi dalam konteks keluarga luas. Sebab lamang dijadikan alat untuk pemberian dari anak ke mertua dari kemanakan ke mamak dan antara ipar dan bisan.

Dalam perkembangan kemudian, tradisi malamang merupakan bagian yang tidak terpisahkan dari kehidupan sosial budaya masyarakat Minangkabau dan selalu dinantikan ketika bulan Ramadhan akan datang, waktu lebaran, Maulud Nabi dan perayaan kematian. Pada waktu itu intensitas hubungan antar keluarga atau kerabat semakin dekat dan akrab karena lemang yang dimasak secara bersama akan dimakan bersama, hidangan untuk tamu, ataupun diantarkan kerumah mintuo (mertua), bako (kerabat ayah), guru mengaji, sahabat, hidangan perayaan maulud Nabi dan lainnya. Sehingga, tradisi malamang tidak hanya sebagai kebiasaan, tetapi juga mencerminkan hubungan yang intim (sosial) dengan kerabat dan masyarakatnya. 


\section{c) Peringatan Kematian}

Masyarakat Sintuk Toboh Gadang merupakan salah satu daerah di Padang Pariaman yang masih mempertahankan tradisi yang hidup dalam masyarakat Tarikat Syatariah yaitu mewajibkan setiap sanak keluarga yang baru saja kehilangan salah seorang saudaranya harus didoakan secara bersama-sama. Tradisi ini berkaitan erat dengan ajaran Syekh Burhanuddin yang membagi acara kematian dari manigo (3) hari, manujuah (7) hari, ampek baleh (14) hari, ampek puluh (40) hari dan manyaratuih (100) hari. Untuk mempertahankan tradisi ini dalam kehidupan masyarakat di Sintuk Toboh Gadang, setiap kaum memiliki surau. Di setiap surau terdapat imam, labai, khatib dan bilal yang merupakan orang-orang yang bertanggung jawab dalam melaksanakan segala akitifitas yang berkaitan dengan tradisi kematian.

Pada masing-masing tahapan tersebut, lamang sebagai salah satu makanan yang harus tersedia. Jumlah lamang yang dimasak pada masing-masing tahapan sesungguhnya berbeda pada saat manigo hari jumlah lamang yang dimasak hanya 3-5 batang. Dalam kehidupan masyarakat Sintuk Toboh Gadang, dikenal dengan istilah lamang ka untuak syariek se (lamang sebagai sebuah syarat). Istilah ini memiliki pengertian keberadaan bahwa lamang hanya untuk kepentingan proses acara manigo hari saja sebab setiap orang tidak akan membawa lamang itu pulang ke rumah masing-masing. Tiga jenis lamang ini harus diberikan kepada urang siak (alim ulama, khatib, bilal dan imam), yang merupakan orang yang bertanggung jawab dalam melaksanakan pembacaan doa, oleh karena itu orang ini mendapatkan perhatian lebih dalam setiap acara kematian di Sintuk Toboh Gadang. Proses pembuatan lamang dalam proses kematian, sang tuan rumah hanya bertindak sebagai penyedia bahan dan alat membuat lamang sedangkan yang bekerja adalah kaum kerabat, sanak saudara, urang sa korong dan sa nagari. Hal ini terkait erat dengan hubungan silaturahmi tuan rumah dengan masyarakat di sekitarnya.

Kebutuhan masyarakat akan lamang semakin banyak seiring dengan hitungan hari digunakan puncaknya adalah pada acara manyaratuih hari, pada saat itu jumlah lamang di masak sampai dengan 30-100 batang. Hal ini berkaitan dengan jumlah orang yang diundang dalam acara tersebut dan banyaknya anak dalam keluarga tersebut. Dalam tradisi masyarakat di Sintuk Toboh Gadang, acara kematian merupakan media silahturahmi antara sanak saudara, ipar dan besan, karena saat itu seluruh pihak saling berkunjung dan membantu. Lamang dijadikan bahan pemberian dari sang tuan rumah terhadap sanak saudara, ipar dan besan yang telah membantu dan hadir dalam acara peringatan kematian yang dilakukan. Hal ini yang menyebabkan 
jumlah lamang yang harus disediakan menjadi lebih banyak, sebab setiap orang yang datang diberi lamang, dan jumlah lamang yang akan diberikan tergantung dengan kedekatan tamu dengan sang tuan rumah. Semakin dekat hubungan yang mereka miliki semakin banyak lamang yang akan diberikan.

Jenis dan varian dari lamang yang harus disediakan oleh tuan rumah juga beragam seperti lamang pisang, lamang ketan, lamang ubi, dan lamang kuning. Kondisi ini terkait erat dengan tersedianya bahan dasar dalam membuat lamang tersebut. Sebagaimana telah dijelaskan, Sintuk Toboh Gadang merupakan daerah pertanian dan perkebunan, kondisi ini menyebabkan seluruh masyarakat di kawasan ini memiliki ubi, pisang dan beras, mendorong mereka membuat lamang dengan rasa lain. Kemampuan masyarakat Sintuk Toboh Gadang dalam membuat lamang dengan jenis dan rasa lain diperkirakan telah berlangsung lama.

Tradisi malamang sebagai sebuah tradisi yang berlaku dalam kehidupan masyarakat Minangkabau, sebagaimana tradisi umumnya, mengandung nilai luhur yang perlu diketahui dan diupayakan kelestariannya. Nilai budaya yang dimaksudkan disini adalah hal-hal yang berharga dari suatu aktifitas dan bernilai luhur, yang mencerminkan budaya masyarakat pengembannya. Dalam konteks tradisi malamang pada masyarakat Minangkabau terkandung adanya nilai, sosial, keagamaan, historis dan ekonomis. Nilai sosial dari tradisi malamang terutama terlihat dari adanya kerjasama atau kegotongroyongan dalam pelaksanaannya dari awal hingga akhir. Nilai keagamaan terlihat dari waktu pelaksananan tradisi yang dalam rangka peringatan Maulud Nabi, menjelang bulan Ramadhan (bulan malamang), menyambut lebaran haji (Idul Adha), peringatan kematian dan lainnya. Nilai historis dari tradisi malamang menunjukkan bahwa tradisi malamang (membuat lamang) telah berlangsung lama atau beberapa abad silam, semenjak agama Islam masuk ke Minangkabau. Sedangkan nilai ekonomis dari malamang tercermin dijadikannya makananlamang sebagai sumber kehidupan (mata pencaharian) dalam keluarga, dan banyak ditemui di pasar-pasar tradisional di Sumatera Barat. Hal ini terlihat dari banyaknya kaum wanita menjual lamang di pasar Kota Padang, Batusangkar, Solok, Pariaman, Bukittinggi, Padangpanjang, Painan dan lainnya. 


\section{PENUTUP}

Tradisi malamang (membuat lamang) merupakan tradisi masyarakat Minangkabau membuat lamang pada waktu-waktu tertentu seperti menjelang bulan puasa (Ramadhan), menyambut bulan haji (Idul Adha), peringatan Maulud Nabi, kematian,dan lainnya. Dari segi historis, konon lamang dan tradisi malamang telah ada semenjak Syech Burhanuddin yang mengenalkan makanan berlapiskan daun pisang dengan wadah berupa talang (bambu) pada masyarakat waktu itu. Tradisi malamang pada dasarnya mengandung nilai budaya masyarakat pengembannya (Minangkabau) yang patut diwarisi oleh masyarakat sekarang seperti nilai sosial (kerjasama, gotongroyong, persatuan dan kesatuan) karena membuat lamang dilakukan secara bersama-sama oleh masyarakat. Nilai lain adalah nilai keagamaan yang tergambar dari pelaksanaannya yang terkait dengan peringatan hari-hari besar agama Islam yakni maulud nabi, lebaran dan lainnya. Sedangkan nilai ekonomi terlihat dari adanya masyarakat yang menjadikan lamang untuk dijual dalam rangka memenuhi kebutuhan sehari-hari.

Tradisi malamang sebagai khasanah budaya Minangkabau seyogyanya tetap dilestarikan terutama nilai luhur yang dikandungnya. Hal itu menjadi tugas pemerintah bersama masyarakat Minangkabau yang perlu dilakukan secara intensif dan berdayaguna bagi kelestarianya, khususnya keahlian membuat lamang dan pelaksanaan tradisi malamang dalam kehidupan sehari-hari masyarakat Minangkabau. Berapa hal yang kiranya bisa dilakukan, seperti;

1. Revitalisasi nilai sejarah dan budaya yang terkandung pada tradisi malamang melalui kegiatan seminar, serasehan, simposium, dialog, gelar budaya dan lainnya.

2. Sosialisasi budaya Minangkabau melalui penyuluhan kepada generasi muda, khususnya tradsisi malamang dengan menjadikannya sebagai muatan lokal dalam kurikululum pendidikan mulai dari Sekolah Dasar (SD) sampai dengan Sekolah lanjutan Tingkat Atas (SLTA).

3. Peran keluarga dan masyarakat dalam mensosialisasi nilai luhur tradisi malamang di kalangan generasi muda, sebab keluarga merupakan wahana utama dan pertama terjadinya pewarisan budaya masyarakat.

4. Upaya mempatentkan lamang sebagai makanan khas milik masyarakat Minangkabau sebelum diambil kepemilikannya oleh masyarakat lain. 


\section{DAFTAR PUSTAKA}

Dananjaya, James. 1991. 'Folklor Indonesia, Ilmu Gosip, Dongeng dan Lain-lan'. Jakarta; Grafiti Press.

Ernayanti. 2003. 'Straregi Pengembangan Kuliner Tradisional' . Skripsi. Denpasar: UNUD Bali.

Navis, AA. 1984. 'Alam Takambang Jadi Guru: Adat dan Kebudayaan Minangkabau'. Jakarta: Pustaka Grafiti Press.

Koentjaraningrat. 1979.' Pengantar Ilmu Antropologi'. Jakarta: Aksara Baru.

1980. 'Sejarah Teori Antropologi'. Jakarta: Universitas Indonesia (UI Press).

Rajab, Muhammad. 1969. 'Sistem Kekerabatan Minangkabau'. Padang: Center for Minangkabau Studies Press.

Refisrul. 1988. 'Wanita Pembuat dan Penjual Lamang, Studi Kasus Kelurahan Balai Labuh Bawah Kecamatan Lima Kaum Kabupaten Tanah Datar'. Skripsi. Padang: Fakultas Sastra.

Riawanti, Selly. 2003. 'Meneliti Tradisi'. Makalah. Jakarta: Direktorat Tradisi dan Kepercayaan.

Scoorl, JW. 1983. 'Modernisasi, Pengantar Sosiologi Pembangunan Negara-negara sedang Berkembang'. Jakarta: Gramedia.

Ahimsa-Putra, Heddy Shri. 2007. 'Peran dan Fungsi Nilai budaya dalam Kehidupan Manusia'. Kertas Kerja/makalah. Yogyakarta: Fakultas Ilmu Budaya UGM.

Supardi, Nunus. 2003. 'Koordinasi Pembinaan Tradisi dan Kepercayaan'. Makalah. Jakarta: Direktorat Tradisi dan Kepercayaan.

Suryani. 2013. 'Pudarnya Tradisi Malamang'. Artikel pada Harian Singgalang Padang. 